\title{
Effect of two volatile oils extracted from Syzygium aromaticum, Mentha longifolia, and imidacloprid on Lucilia cuprina (Diptera: Calliphoridae)
} Original Article

\author{
Karima S Khater
}

Zoology Department, Faculty of Science, Zagazig University, Zagazig-44519, Sharkia, Egypt

\begin{abstract}
Background: The third larval instar (L3) of Lucilia cuprina grow and feed on the living flesh of sheep. Besides, they cause cutaneous myiasis. Herbal medicine showed potential efficacy against several pathogens as well as insecticidal effects.

Objectives: The present work aims to investigate effect of two volatile oils, Syzygium aromaticum, Mentha longifolia and the chemical neonicotinoid, imidacloprid (IMI), on the developmental stages of L. cuprina.

Material and Methods: Early L3 of L. cuprina were exposed to five concentrations of the three selected compounds under investigation. The procedures were replicated four times for each concentration, and 25 larvae were used for each replicate. Average larval mortality rates were subjected to probit model analysis for calculating $\mathrm{LC}_{25}, \mathrm{LC}_{50}, \mathrm{LC}_{90}$. Activity of acetylcholine esterase (AchE), as a measure of anticholinesterase activity of the used compounds, was measured using acetylcholine bromide (AchBr) as substrate.

Results: It was observed that the volatile oil $\mathrm{LC}_{50}$ of $M$. longifolia (3.35\%) gave higher mortality of L3 compared with that produced by S. aromaticum oil (6.06\%), whereas IMI was the most effective larvicidal agent with $\mathrm{LC}_{50}$ of $0.000853 \%$. Both volatile oils induced complete disintegration in epicuticle and the epidermis of larval integument, and extensive damage of epithelial cells of midgut. Treatments by both oils and IMI induced deformed adult flies, with significant larval mortality and the highest pupal mortality, compared to controls. The AchE activity showed insignificant reduction after treatment with the $\mathrm{LC}_{50}$ of both essential oils and IMI.

Conclusion: The inhibitory effect of the two volatile oils and IMI on the biology, histology and AchE activity suggested that they may be considered as control agents against the myiasis causing fly L. cuprina.
\end{abstract}

Keywords: acetylcholine esterase enzyme, histology, imidaclopride, Lucilia cuprina, Mentha longifolia, Syzygium aromaticum, toxicity, volatile oils.

Received: 1 December, 2020, Accepted: 21 February, 2021.

Corresponding Author: Karima S Khater, Tel.: +20 1093426278, E-mail: k.shoukry@zu.edu.eg

Print ISSN: 1687-7942, Online ISSN: 2090-2646, Vol. 14, No. 1, April, 2021.

\section{INTRODUCTION}

Myiasis is the invasion of animal and human tissue by dipteran larvae ${ }^{[1]}$. Lucilia is considered one of the most important blowflies because it causes facultative myiasis in animal and human dead bodies ${ }^{[2]}$. It belongs to the blowfly family Calliphoridae. Lucilia species are distributed in many geographical localities and are agents of some medical problems such as secondary infection by viruses and bacteria ${ }^{[3]}$. Due to feeding on animal and human excrement and refuse, blowflies can spread microbiomes through contamination ${ }^{[4]}$. In fact, blowflies have shown great ability to convey a variety of bacteria, protozoans, cestodes, and viruses of medical importance such as Salmonella typhimurium ${ }^{[5]}$ Entamoeba coli, Taenia spp. and Giardia duodenalis ${ }^{[6]}$. Besides, blowfly infestations lead to losses in the animal industry ${ }^{[7,8]}$. Lucilia cuprina, commonly called Australian sheep blowfly, is a serious pest that affects the animal and wool trade ${ }^{[9]}$. Its larvae cause cutaneous myiasis; they grow while eating the live flesh of sheep, and in heavy infestations they lead to death of sheep when left without treatment[10].
The employment of synthetic chemical insecticides to control insects led to several environmental problems, as insect resistance and toxic effects on non-target and beneficial organisms. In many cases, synthetic insecticides lead to poisoning of persons assigned for their application ${ }^{[11]}$. Resistance of $L$. cuprina to organophosphrous, organochlorine and benzoyl-phenyl urea has been recorded ${ }^{[12,13]}$. It is vital to search for other environmentally safe methods for insect control. The use of plant extracts and their derivatives proved potent against many insects; in addition to their low mammalian toxicity and high biodegradable rate ${ }^{[14]}$.

Essential oils composed of mixtures of bioactive compounds, are secondary metabolites abundant in aromatic plants. These oils contain a number of compounds such as monotrepens and sesquiterpens ${ }^{[15]}$, used as contact, fumigant insecticides ${ }^{[16]}$ as well as anti-food agents ${ }^{[17]}$. Volatile oils possess aromatic properties that compel insects 
to reduce or stop feeding ${ }^{[18]}$. Moreover, volatile oils were used as repellents ${ }^{[19]}$ subsequently delaying development and growth ${ }^{[20]}$. The activity of essential oils is related to their chemical composition ${ }^{[21]}$. Compounds of volatile oils have neurotoxic activities including several mechanisms as inhibition of cytochrome P450 enzymes, acetylcholine esterase, gamma aminobutyric acid receptors and blocking of octapamine receptors ${ }^{[22]}$.

Mentha longifolia L., commonly known as wild mint or horse mint, belongs to family Lamiaceae and grows in Mediterranean regions, Europe, Australia, and North Africa ${ }^{[23]}$. Different parts of $M$. longifolia are used in traditional medicine, food industries and in pharmaceutics (anti-microbial, anti-spasmodic, treatment of headaches and digestive disorders) ${ }^{[24]}$. The volatile oil of $M$. longifolia depresses ${ }^{[25]}$ the central nervous system of the fly and has repellent effects against the maize weevil (Sitophilus zeamais) and the red flour beetle (Tribolium castaneum) ${ }^{[26]}$.

Syzygium aromaticum L., commonly called clove, belongs to the family Myrtaceae, and is an important aromatic spice. Clove oil besides being widely used for flavoring pastry as well as in medicines ${ }^{[27]}$, it has enormous biological activities such as anti-microbial (anti-bacterial and anti-fungal), insecticidal and antioxidant properties ${ }^{[28-30]}$.

It is worth mentioning that IMI (35\%), [1-(6-chloronicotinyl)-2-nitroimino-imidazolidine], is a member of neonicotinoid insecticide family. It is widely used as a systemic compound for plant protection against insects that suck plant juice and cause severe damage to crop. Such compounds are effective against aphids, leaf hoppers and whiteflies ${ }^{[31]}$. Neonicotinoids are neurotoxins used in veterinary medicine to kill parasites of domestic animals such as ticks, fleas, and worms by interfering with conduction of nerve impulses and blocking AchE receptors ${ }^{[32,33]}$. They induce accumulation of acetylcholine and neuronal hyperexcitation, leading to convulsions and death within minutes $^{[34,35]}$. In vertebrates, IMI does not pass easily through skin and penetrates the lining of the digestive system, especially the intestine, when taken with food. However, it was reported that neonicotinoids do not pose any threat to humans if they are used according to the product label and stored in places not accessible to children. It has lower affinity for interacting with the nicotinic AchE receptors of vertebrates than those present in insects ${ }^{[36]}$.

The objective of the current investigation attempt is to introduce an ecofriendly source for myiasis control by providing new insight on the activity of volatile oils of $S$. aromaticum and $M$. longifolia compared to IMI against L3 of L. cuprina under laboratory conditions. In addition, AchE level was determined as a measure of anti-cholinesterase activity of the compounds under investigation

\section{MATERIAL AND METHODS}

In this case control study, all experiments were carried out during the year 2018 at the Entomology laboratory, Zoology Department, Faculty of Sciences, Zagazig University.

Extraction of volatile oils: The plants under investigations were obtained from Sharkia governorate. The volatile oils were extracted from flower buds of $S$. aromaticum and from leaves and stems of $M$. longifolia. The plant oils were extracted by steam distillation using $300 \mathrm{~g}$ of plants in $300 \mathrm{ml}$ water for $4-6 \mathrm{~h}^{[37,38]}$. The distillate was received over anhydrous sodium sulphate in a special container. The isolated oils had a pale-yellow color, and individual characteristic strong odor. The oils were stored in dark glass bottles in the refrigerator at $4^{\circ} \mathrm{C}$. Additionally, IMI (35\%) was obtained as an emulsified insecticide, from Physiology laboratory in Plant Protection Research Institute, Dokki, Giza, Egypt (Zagazig Branch).

Insect colony: Buffalo meat was exposed outdoors for oviposition of different flies. Hatched larvae were reared in plastic jars $(10.5 \times 7 \mathrm{~cm})$ containing approximately $50 \mathrm{gm}$ fresh buffalo meat. About 50 larvae were kept in each plastic jar to avoid competition. The pupae were transferred to new plastic jars containing sawdust as medium for pupation. The pupae were obtained by sieving and transferred to rearing cages $(30 \times 30$ x $30 \mathrm{~cm}$ ) for adult emergence. To obtain a L. cuprina susceptible strain, emerging adults were identified morphologically as described ${ }^{[39]}$, separated and reared for three generations under laboratory conditions $\left(25 \pm 2^{\circ} \mathrm{C}\right.$ and $54-73$ relative humidity). To maintain the colony, flies were supplied with $10 \%$ sucrose solution, sugar crystals and offered fresh meat and cotton soaked in milk as a source of protein and medium for egg deposition ${ }^{[40]}$.

Effects of volatile oils and IMI: Early L3 of L. cuprina were exposed to five different concentrations of the three selected compounds under investigation $7,5,3$, $1,0.5 \%$ for the two botanical volatile oils and 0.005 , $0.0025,0.00125,0.000625$ and $0.00031 \%$ for IMI. The procedures were replicated four times for each concentration. Twenty-five larvae were used for each replicate. Two $\mathrm{ml}$ of each concentration were added to $20 \mathrm{gm}$ of minced meat in a glass jar $(6 \times 9 \mathrm{~cm})$. In the control experiment, water with tween was used to replace the volatile oils; and water only was used for IMI control experiment. Experiments were carried out under laboratory conditions at $27 \pm 2^{\circ} \mathrm{C}, 80 \pm 5 \%$ relative humidity, and 16: 8 light: dark cycle ${ }^{[41]}$. Larval mortality was recorded $48 \mathrm{~h}$ after treatments ${ }^{[42]}$.

Histological studies: The effects of median lethal concentrations $\mathrm{LC}_{50}$ of the essential oils of $S$. aromaticum, M. longifolia and IMI on histology of early L3 were investigated. For each experiment, five test and 
control larvae were immediately placed in aqueous Bouin's fixative after $24 \mathrm{~h}$ treatment and refrigerated at $5^{\circ} \mathrm{C}$ for $2 \mathrm{~h}$. After dehydration in graded ascending series of ethanol $(70 \%, 80 \%, 90 \%$ and $100 \%)$, the larvae were embedded in liquid paraffin. Histological sections were prepared and stained with hematoxylin and eosin stains ${ }^{[43]}$.

Determination of AchE activity: The larvae were homogenized in distilled water (50 mg larval tissue/ $\mathrm{ml}$ distilled water) then centrifuged at $8000 \mathrm{rpm}$ for $15 \mathrm{~min}$ at $2^{\circ} \mathrm{C}$ in a refrigerated centrifuge (Microspin 12 , Germany). The supernatants considered as enzyme extracts, were stored at $5^{\circ} \mathrm{C}$ for up to one week without appreciable loss of activity which was measured using $\mathrm{AchBr}$ as substrate ${ }^{[44]}$. The reaction mixture contained $200 \mu \mathrm{l}$ enzyme solution, $0.5 \mathrm{ml} 0.067 \mathrm{M}$ phosphate buffer ( $\mathrm{pH} 7$ ), and $0.5 \mathrm{ml} \mathrm{AchBr}(3 \mathrm{mM})$. The test tubes were incubated at $37^{\circ} \mathrm{C}$ for exactly 30 min. One $\mathrm{ml}$ alkaline hydroxylamine (equal volume of $2 \mathrm{M}$ hydroxylamine chloride and $3.5 \mathrm{M} \mathrm{NaOH}$ ) was added to the test tubes. Then, $0.5 \mathrm{ml}$ of $\mathrm{HCl}(1$ part of concentrated $\mathrm{HCl}$ and 2 parts of hot water) was added. The mixture was shaken vigorously and allowed to stand for $2 \mathrm{~min}$, and $0.5 \mathrm{ml}$ of ferric chloride solution (0.9 $\mathrm{M} \mathrm{FeCl} 3$ in $0.1 \mathrm{M} \mathrm{HCl})$ was added. The decrease in $\mathrm{AchBr}$ resulting from hydrolysis by AchE was determined at $515 \mathrm{~nm}^{[44]}$.

Statistical analysis ${ }^{[45,46]}$ : Average larval mortality rates were subjected to probit model analysis for calculating $\mathrm{LC}_{25}, \mathrm{LC}_{50}$, and $\mathrm{LC}_{90}$. The results were analyzed by one-way analysis of variance (ANOVA) using Costat Statistical Software, 1990, Version 4.2, Cohort Software, Berkeley, California. Significance levels were calculated using Chi-square test for lethal concentrations, and least significance differences (LSD) test for quantitative data (means \pm standard error). Significance was considered when $P$ value was less than 0.05 .

Ethical consideration: This study was performed using commercially available plants and IMI. No human specimens were examined. No in vivo experiments were conducted. Initially, larvae of flies used were collected from meat exposed outdoors. All experimental issues were approved by the Zoology Department, Faculty of Sciences, Zagazig University.

\section{RESULTS}

Toxicological studies: The data presented in table (1) showed that the larvae were more susceptible to wild mint (M. longifolia) oil than clove (S. aromaticum) oil at $\mathrm{LC}_{50}$ value of $3.35 \%$ and $6.06 \%$, respectively. While the synthetic IMI showed the most toxic $\mathrm{LC}_{50}$ value of $0.000853 \%$

The results showed that percentage of larval mortality increased with increase of lethal concentration (Table 2). The volatile oils of $M$. longifolia gave higher larval mortality percent compared with that from S. aromaticum. Significant pupal mortalities were observed after treatment with 5,3 and $1 \%$ of $M$. longifolia, and $1 \%$ of $S$. aromaticum. Significant reduction $(P<0.0001)$ was registered in mean number of emerged adult males following treatment with $7 \%$ of both $S$. aromaticum and $M$. longifolia by $3 \pm 0.70$ and $1.5 \pm 0.08$, respectively compared with the control experiment $(10 \pm 0.70)$. Also, significant reduction in number of emerged females $(P<0.0001)$ was recorded after treatment with the same concentration of $M$. longifolia and $S$. aromaticum by $2.25 \pm 0.47$ and $1.5 \pm$ 0.28 , respectively compared with control $(14.5 \pm 0.50)$. The volatile oil of $S$. aromaticum and M. longifolia treatments induced deformed adult individuals. $S$. aromaticum volatile oil showed the highest number of deformations in emerged adults after treatment with $0.5,1$ and $3 \%$ concentrations by $7.5 \pm 0.28,6.5 \pm 0.5$ and $4.25 \pm 0.85$, respectively (Table 2 ).

After treatment with IMI, significant larval mortality $(P<0.0001)$ was recorded at $0.005 \%$ reaching $22.75 \pm 0.63$ compared to control. The highest pupal mortality was observed after treatment with $0.00031 \%$ scoring $5.25 \pm 0.47$ compared to control. The mean number of emerged males was significantly reduced $(P<0.0001)$ to $0.5 \pm 0.50$ and $1.0 \pm 0.0$ after treatment with 0.0025 and $0.005 \%$, respectively. The mean number of emerged females was significantly reduced $(P=0.011)$ to $0.50 \pm 0.28$ after treatment with $0.005 \%$ compared with $14 \pm 0.50$ in control. The deformed adult recorded $1.5 \pm 0.50$ after treatment with $0.000625 \%$ (Table 2).

The histopathological studies: The integument of normal L3 of L. cuprina consists of the cuticle,

Table 1. The efficacy of S. aromaticum, M. longifolia volatile oils and IMI on L3 of L. cuprina after $48 \mathrm{~h}$ treatment.

\begin{tabular}{lccc}
\hline \hline & & \multicolumn{3}{c}{ Lethal concentrations } \\
\cline { 2 - 4 } Lethal concentrations & S. aromaticum (\%) & M. longifolia (\%) & IMI (\%) \\
\hline LC $_{\text {25 }}$ (LCL- UCL) & $1.78(1.34-2.23)$ & $0.96(0.66-1.26)$ & $0.000431(0.000347-0.00051)$ \\
CC $_{\text {5 }}$ (LCL- UCL) & $6.06(4.71-8.61)$ & $3.35(2.70-4.30)$ & $0.000853(0.000727-0.000956)$ \\
CC $_{\mathbf{9 0}}$ (LCL- UCL) & $62.02(32.79-137.14)$ & $35.73(21.00-81.39)$ & $0.002927(0.002328-0.004021)$ \\
\hline Statistical analysis & & & \\
Slope \pm SE & $1.26 \pm 0.15$ & $1.24 \pm 0.145$ & $2.35 \pm 0.17$ \\
Chi-square test (DF=4) & 1.49 & $<0.20$ & 20.15 \\
$P$ value & $<0.0001^{*}$ & $<0001^{*}$ & $<0.0001^{*}$ \\
\hline \hline
\end{tabular}

IMI: Imidacloprid; LCL: Lower confidence limits; UCL: Upper confidence limits; SE: Standard error; DF: Degree of freedom. *: Significant. 
Table 2. Effect of treatment with S. aromaticum, M. longifolia volatile oils and IMI on larval mortality, pupal mortality, and adult emergence of L. cuprina after $48 \mathrm{~h}$ feeding of L3 on treated diet.

\begin{tabular}{|c|c|c|c|c|c|c|}
\hline \multirow[b]{2}{*}{ Compound } & \multirow{2}{*}{$\begin{array}{l}\text { Conc. } \\
\text { Unit }^{@}\end{array}$} & \multicolumn{2}{|c|}{ Immature stages mortality } & \multicolumn{3}{|c|}{ Adult emergence } \\
\hline & & $\begin{array}{c}\text { Larval } \\
\text { (Mean } \pm \text { SE) }\end{array}$ & $\begin{array}{c}\text { Pupal } \\
(\text { Mean } \pm \text { SE) }\end{array}$ & $\begin{array}{c}\text { Male } \\
\text { (Mean } \pm \text { SE) }\end{array}$ & $\begin{array}{c}\text { Female } \\
(\text { Mean } \pm \text { SE })\end{array}$ & $\begin{array}{l}\text { Deformed adults } \\
\quad \text { (Mean } \pm \text { SE) }\end{array}$ \\
\hline \multirow{5}{*}{$\begin{array}{c}\text { S. aromaticum } \\
(\%)\end{array}$} & 7 & $14.0 \pm 0.82^{\mathrm{a}}$ & $6.5 \pm 0.5^{\mathrm{a}}$ & $3.0 \pm 0.70^{\mathrm{d}}$ & $1.5 \pm 0.28^{c}$ & $0.0 \pm 0.0^{\mathrm{d}}$ \\
\hline & 5 & $11.5 \pm 0.86^{\mathrm{b}}$ & $7.0 \pm 0.40^{\mathrm{a}}$ & $3.25 \pm 0.25^{\mathrm{d}}$ & $1.75 \pm 0.25^{c}$ & $2.0 \pm 0.70^{c}$ \\
\hline & 3 & $7.5 \pm 0.28^{c}$ & $3.75 \pm 0.25^{\mathrm{b}}$ & $4.0 \pm 1.15^{\mathrm{cd}}$ & $5.0 \pm 1.0^{\mathrm{b}}$ & $4.25 \pm 0.85^{\mathrm{b}}$ \\
\hline & 1 & $4.25 \pm 0.47^{d}$ & $2.75 \pm 0.47^{c}$ & $6.0 \pm 0.40^{\mathrm{b}}$ & $5.5 \pm 0.28^{b}$ & $6.5 \pm 0.5^{\mathrm{a}}$ \\
\hline & 0.5 & $2.25 \pm 0.25^{\mathrm{e}}$ & $3.5 \pm 0.28^{\mathrm{bc}}$ & $5.5 \pm 0.28^{\mathrm{bc}}$ & $5.5 \pm 0.28^{\mathrm{b}}$ & $7.5 \pm 0.28^{\mathrm{a}}$ \\
\hline \multirow{5}{*}{$\begin{array}{c}\text { M. longifolia } \\
\text { (\%) }\end{array}$} & 7 & $17.0 \pm 0.40^{\mathrm{a}}$ & $3.25 \pm 0.25^{\mathrm{a}}$ & $1.5 \pm 0.08^{\mathrm{d}}$ & $2.75 \pm 0.47^{\mathrm{d}}$ & $0.5 \pm 0.28^{\mathrm{cd}}$ \\
\hline & 5 & $14.75 \pm 0.25^{b}$ & $2.25 \pm 0.47^{\mathrm{b}}$ & $3.0 \pm 0.40^{\mathrm{d}}$ & $4.0 \pm 0.40^{\mathrm{cd}}$ & $1.0 \pm 0.40^{\text {cd }}$ \\
\hline & 3 & $10.75 \pm 0.25^{c}$ & $1.50 \pm 0.28^{\mathrm{b}}$ & $5.5 \pm 0.28^{c}$ & $4.5 \pm 0.28^{c}$ & $2.75 \pm 0.25^{\mathrm{ab}}$ \\
\hline & 1 & $6.5 \pm 0.64^{\mathrm{d}}$ & $1.50 \pm 0.28^{\mathrm{b}}$ & $9.5 \pm 0.28^{\mathrm{ab}}$ & $6.0 \pm 0.40^{\mathrm{b}}$ & $0.5 \pm 0.65^{\mathrm{bc}}$ \\
\hline & 0.5 & $4.0 \pm 0.40^{\mathrm{e}}$ & $4.0 \pm 0.40 \mathrm{a}$ & $8.0 \pm 0.40^{\mathrm{b}}$ & $6.0 \pm 0.70^{\mathrm{b}}$ & $3.0 \pm 0.58^{\mathrm{a}}$ \\
\hline \multirow{5}{*}{ IMI (ppm) } & 50 & $22.75 \pm 0.63^{\mathrm{a}}$ & $0.50 \pm 0.28^{\mathrm{d}}$ & $1.0 \pm 0.0^{c}$ & $0.50 \pm 0.28^{\mathrm{e}}$ & $0.25 \pm 0.25^{b}$ \\
\hline & 25 & $22.25 \pm 0.75^{\mathrm{a}}$ & $0.50 \pm 0.50^{\mathrm{d}}$ & $0.50 \pm 0.50^{c}$ & $1.75 \pm 1.18^{\text {ed }}$ & $0.0 \pm 0.0^{\mathrm{b}}$ \\
\hline & 12.5 & $16.25 \pm 0.75^{b}$ & $1.50 \pm 0.28^{c}$ & $3.50 \pm 0.86^{b}$ & $3.50 \pm 0.65^{\mathrm{bc}}$ & $0.25 \pm 0.25^{\mathrm{b}}$ \\
\hline & 6.25 & $8.25 \pm 0.85^{c}$ & $3.25 \pm 0.62^{\mathrm{b}}$ & $8.75 \pm 1.25^{\mathrm{a}}$ & $3.25 \pm 0.95^{\mathrm{bc}}$ & $1.5 \pm 0.50^{\mathrm{a}}$ \\
\hline & 3.125 & $4.75 \pm 0.85^{\mathrm{d}}$ & $5.25 \pm 0.47^{\mathrm{a}}$ & $9.50 \pm 0.28^{\mathrm{a}}$ & $5.0 \pm 0.40^{\mathrm{b}}$ & $0.50 \pm 0.28^{\mathrm{b}}$ \\
\hline Control & & $0.5 \pm 0.28$ & $0.0 \pm 0.0$ & $10.0 \pm 0.70$ & $14.5 \pm 0.50$ & $0.0 \pm 0.0$ \\
\hline
\end{tabular}

IMI: Imidacloprid. Conc. Unit ${ }^{\circledR}: \%$ and ppm are the concentration units for both volatile oils and IMI, respectively. Each datum represents the mean and standard error (SE) of four replicates. All concentrations showed significant results $(P<0.05)$ compared with control. Means within the same column followed by the same superscript are not significantly different (LSD test, $P>0.5)$; while means of other concentrations with different symbols within the same column are significant $(P<0.0001)$.

hypodermis, and basement membrane. The cuticle consists of epicuticle, exocuticle, and endocuticle (Fig. 1a). A well-formed muscle layer underlies the outer cuticular layer. The muscle layer is composed of striated fibers. Each muscle fiber consists of a number of parallel myofibrils, occupying the whole of the cross section of the fiber (Fig. 1a). The normal fat bodies are composed of two distinct layers. An outer layer which constitutes ribbons underlying the body wall, and a

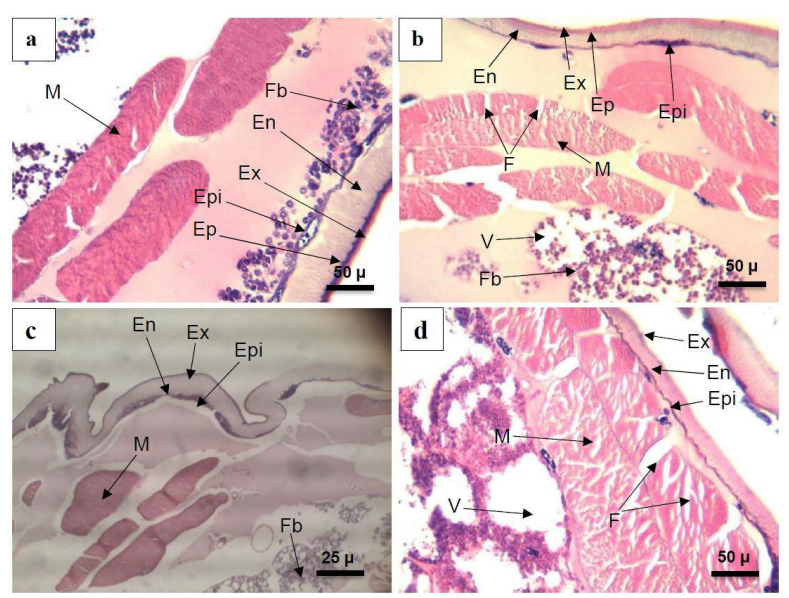

Fig. 1. Photomicrographs of transverse sections of $L$. cuprina larvae showed: a) Normal cuticle consisting of exo, epi and endocuticle, muscles and subcutaneous fat bodies; b) Treatment with $\mathrm{LC}_{50}$ of $S$. aromaticum oil showed fissures in muscles and vacuoles in fat bodies; c) Treatment with $\mathrm{LC}_{50}$ of M. longifolia oil showed lack of differentiation between epicuticle and endocuticle and vacuolization in fat bodies, degeneration in exocuticle and epicuticle and disorganization of epidermal cells; d) Treatment with $\mathrm{LC}_{50}$ of IMI showed lack of differentiation between exo-cuticle and endocuticle, vacuolation in fat bodies and fragmentation of muscles. En: endocuticle; Ep: epicuticle; Epi: epidermis; Ex: exocuticle; F: fissures; Fb: fat bodies; $\mathbf{M}$ : muscles; V: vacuole. visceral layer lying between the various organs (Fig. 1a).

Severe damage occurred to the integument of $L$. cuprina larvae when they were treated by the three compounds. Complete disintegration in epicuticle and the epidermis of larval integument and folding in some regions was observed after treatment with $M$. longifolia (Fig. 1c). Thinning of cuticle, a lack of differentiation between epicuticle, exocuticle and endocuticle were elicited after $S$. aromaticum and IMI treatment (Fig. $1 \mathrm{~b}, \mathrm{~d})$. The noted histological aberrations included destruction of the fat body cells with vacuolization following application of the three tested compounds (Fig. 1b, c, d). Their effect on muscles ranged between slight degeneration seen as fissures (Fig. 1b, c), to complete destruction of the whole tissue by IMI (Fig. 1d).

Anatomically, the alimentary canal of normal $L$. cuprina larva consists of foregut, midgut, and hindgut that is strongly convoluted in the body cavity. The larval midgut is the longest and most efficient portion of the alimentary canal where digestion and absorption take place. There are several gastric caeca and Malpighian tubules associated with the alimentary canal. It is worth mentioning that the foregut in dipteran larva consists of esophagus, crop and cardia that is divided into two parts; an anterior and a posterior region. The posterior region has the similar histology of midgut that is why it is called posterior midgut of foregut cardia. Histologically, it consists of a single layer of columnar epithelial cells containing rounded basophilic nuclei, resting on a basement membrane, and is wrapped by a layer of outer longitudinal and inner circular muscles; 
and the lumen contains the peritrophic membrane (Fig. 2a). Histopathological alterations were clearly observed following exposure to the three compounds under investigations. Treatment by $S$. aromaticum oil showed detachment between the epithelial cells and the basement membrane. The cell membranes do not remain separated and merge together forming the syncytium (Fig. 2b). Similarly, degeneration and necrosis occurred after $M$. longifolia treatment (Fig. 2c); and complete lysis followed IMI application (Fig. 2d).

The wall of the normal salivary gland consists of a small number of large cells with rounded nuclei enclosing a relatively large lumen (Fig. 3a). Degeneration of some salivary gland cells (Fig. 3b, c)

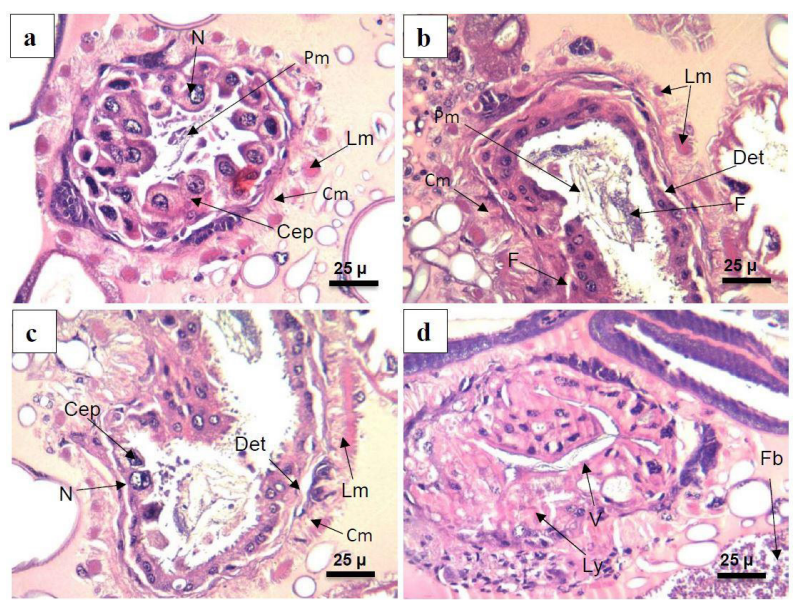

Fig. 2. Photomicrographs of transverse sections of L. cuprina larvae in posterior cardia with midgut tissue of fore gut region showed a) Normal posterior cardia consisting of a single layer of columnar epithelium wrapped with outer longitudinal muscles and inner circular muscles layer; b) Larvae treated with $\mathrm{LC}_{50}$ of $S$. aromaticum oil with detachment of foregut epithelium from the muscular layer and boundaries between epithelial cells disappeared; c) Larvae treated with $\mathrm{LC}_{50}$ of M. longifolia oil with appearance of vacuoles, degenerated cardial epithelial cells, detachment of basement membrane and boundaries between epithelial cells forming a syncytium; d) Larvae treated with $\mathrm{LC}_{50}$ of IMI with lysis of cells and all tissues. Cep: cuboidal epithelium; Det: detachment; Fb: fat bodies; M: muscles; N: nucleus; Ly: lysis; V: vacuole.

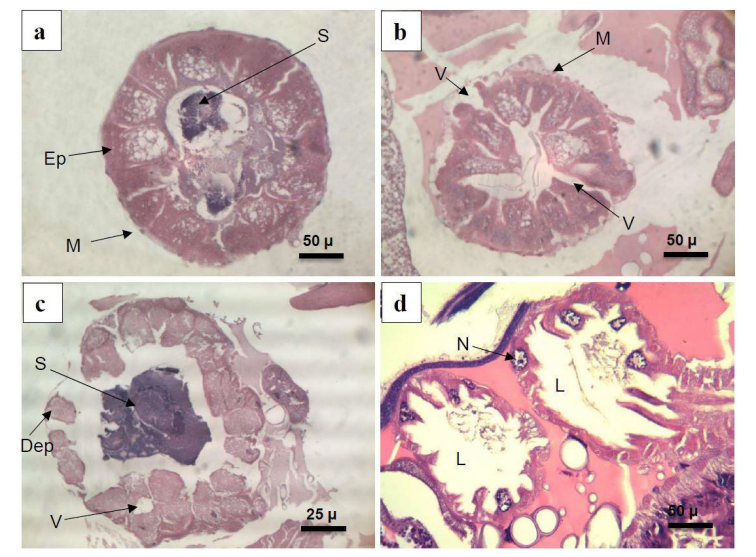

and rupture of the wall of the salivary glands were observed following treatment by the two volatile oils (Fig. 3b, c), while the cells became elongated with signs of necrosis after treatment with IMI (Fig. 3d).

In the untreated larvae of L. cuprina, the gastric caecum has a distinct layer of epithelial cells. The caecal cells have ovoid centrally located nuclei (Fig. 4a). After S. aromaticum oil treatment, the caecal epithelial cells showed vacuolations between caecal cells and muscle layer (Fig. 4b). Some cells appeared degenerated, some were hypertrophied, and some were vacuolated after M. longifolia oil treatment (Fig. 4c). Treatment with IMI induced degeneration of cells and enlargement of lumen (Fig. 4d).

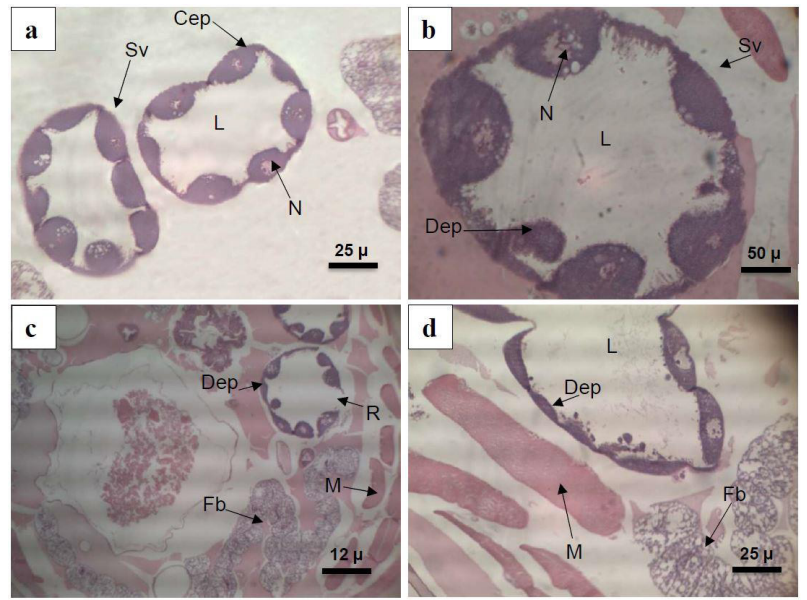

Fig. 3. Photomicrographs of transverse sections in salivary gland of L. cuprina larvae showed a) Normal structure with single layer of epithelial cells enclosing a large lumen; b) Larvae treated with $\mathrm{LC}_{50}$ of $S$. aromaticum oil with degenerated epithelium; c) Larvae treated with $\mathrm{LC}_{50}$ of $M$. longifolia oil with rupture of epithelial layer; d) Larvae treated with $\mathrm{LC}_{50}$ of IMI with degenerated epithelium.

Cep: cuboidal epithelium; Dep: degenerated epithelium; Fb: fat bodies; L: lumen; M: muscles; N: nucleus; R: rupture; Sv: salivary gland.

Fig. 4. Photomicrographs of transverse sections of gastric ceaca in L. cuprina larvae showed a) Normal structure of single columnar epithelial layer sheathed by thin muscular layer and enclosing lumen filled with secretion; b) Larvae treated with $\mathrm{LC}_{50}$ of $S$. aromaticum oil with elicited detachment of epithelial cells from muscular layer and appearance of vacuoles between cells; c) Larvae treated with $\mathrm{LC}_{50}$ of M. longifolia oil with complete degeneration of muscular layer and degeneration of some cells; d) Larvae treated with $\mathrm{LC}_{50}$ of IMI with induced degeneration of epithelial cells and enlargement of lumen. Cm: circular muscles; Dep: degenerated epithelium; Det: detachment; L: lumen; Lm: longitudinal muscles; M: Muscles; N: nucleus; S: secretion; V: vacuole. 
The normal midgut region also consists of a single layer of columnar epithelial cells resting on a basement membrane and surrounded by thin muscle layer. The midgut lumen contains a peritrophic membrane enclosing food particle (Fig. 5a). Treatment with $S$. aromaticum and $M$. longifolia oils induced a severe effect on the mid-gut, with shrinkage of some epithelial cells and swelling of other cells (Fig. 5b, c). Appearance of large vacuoles was detected after IMI treatment (Fig. $5 \mathrm{~d})$. The boundaries of epithelial cells were extensively damaged, showing a great destruction of muscular cells, necrotic epithelium, and detachment of the basement membrane (Fig. 5b, c).

The normal Malpighian tubule consists of a single layer of flattened cells with indistinct borders. These cells are lined internally by a distinct brush border (Fig. 6a). Malpighian tubules of larvae treated with LC50 of $S$. aromaticum and $M$. longifolia oil showed obvious coagulation of microvilli (Fig. 6b). After application of $\mathrm{LC}_{50}$ of IMI, appearance of vacuoles, rupture of cells and clumping of microvilli were observed (Fig. 6c).

The normal trachea is a rigid tube consisting of an outermost layer of flattened epithelial cells with clear basophilic nuclei. This cellular layer is followed by ridge- like circumferential rings, called taenidia. The trachea is strengthened by a spiral folding ring of cuticle, the intima, that encloses the tracheal lumen (Fig. 6d). Application of the three tested compounds induced the same effect on the trachea that appeared collapsed with diminished lumen (Fig. 6e).

Acetylcholinesterase activity: The AchE activity showed insignificant reduction after treatment with the $\mathrm{LC}_{50}$ of the two volatile oils and, IMI. Data in figure (7) showed that treatment with IMI provoked the most inhibitory effect by $4.05 \pm 0.036 \mu \mathrm{g} \mathrm{AchBr} / \mathrm{min} /$ mg protein compared with $5.386 \pm 0.05 \mu \mathrm{g}$ AchBr/min/ mg protein in control experiment. Treatment with $S$. aromaticum and $M$. longifolia caused the same effect by $4.85 \pm 0.08$ and $4.83 \pm 0.07 \mu \mathrm{g} \mathrm{AchBr} / \mathrm{min} / \mathrm{mg}$ protein, respectively.

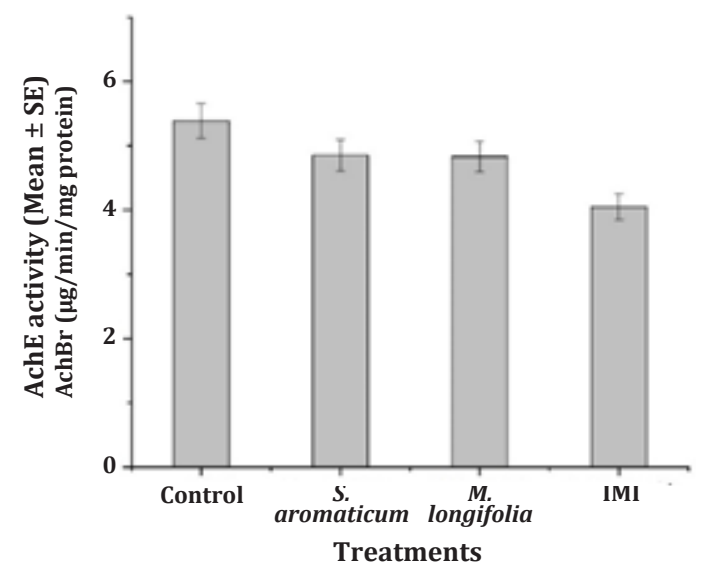

Fig. 7. Effect of treatments with volatile oils of $S$. aromaticum, M. longifolia volatile oils, and IMI on AchE activity of L. cuprina larvae.

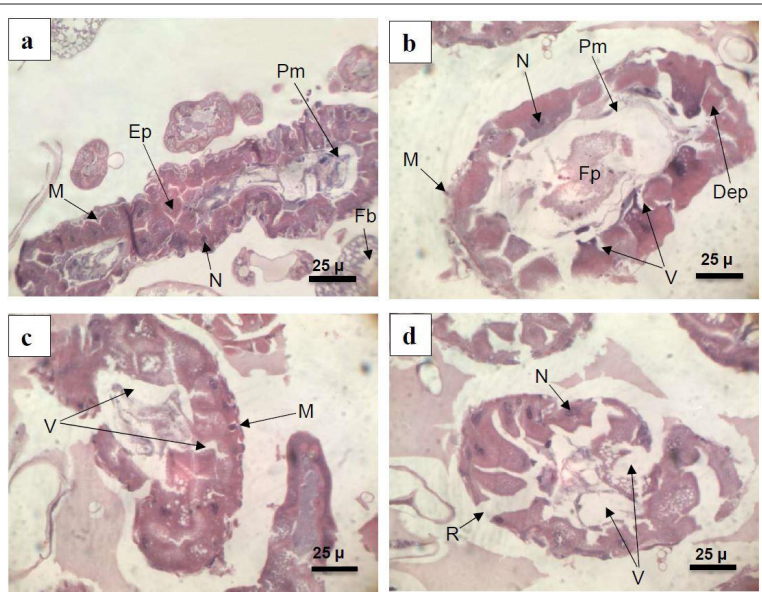

Fig. 5. Photomicrographs of transverse sections of $L$. cuprina larvae in midgut showed a) Normal midgut histology of simple layer of columnar epithelium enclosing a lumen containing peritrophic membrane and food particles; b) Midgut treated with $\mathrm{LC}_{50}$ of $S$. aromaticum oil with appearance of vacuoles between the cells and rupture of peritrophic membrane; c) Midgut treated with $\mathrm{LC}_{50}$ of $M$. longifolia oil presenting cell rupture; d) Midgut treated with $\mathrm{LC}_{50}$ of IMI with cellular necrosis.

Dep: degenerated epithelium; Ep: epithelial cells; Fb: fat bodies; Fp: food particles; M: muscle; N: nucleus; Pm: peritrophic membrane; R: rupture; $\mathbf{V}$ : vacuole.

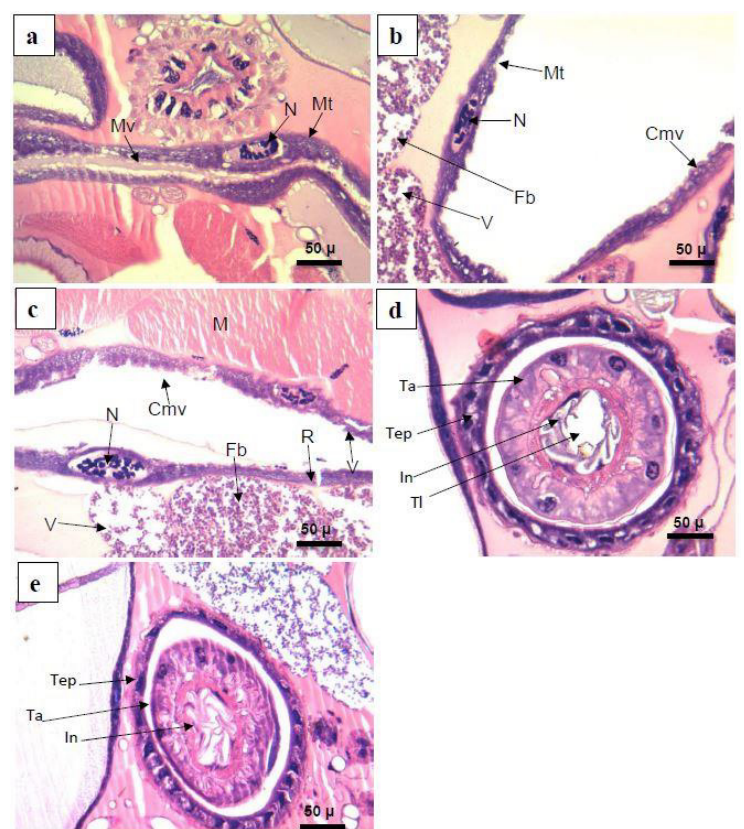

Fig. 6. Photomicrographs of transverse sections of $L$. cuprina larvae showed a) Normal Malpighian tubules consisting of a single layer of flattened epithelial cell with clear microvilli and oval nucleus; b) Malpighian tubules of larvae treated with $\mathrm{LC}_{50}$ of $S$. aromaticum and $M$. longifolia oil with coagulation of microvilli; c) Malpighian tubules of larvae treated with $\mathrm{LC}_{50}$ of IMI with appearance of vacuoles, rupture of cells and clumping of microvilli; d) Normal trachea consisting of outer layer of tracheal epithelium followed by taenidium with intima and enclosing tracheal lumen; e) Trachea after treatment with $\mathrm{LC}_{50}$ of $S$. aromaticum, $M$. longifolia oil and IMI with hypotrophy of tracheal epithelium, appearance of vacuoles in taenidium and collapsed tracheal lumen.

Cmv: coagulated microvilli; Fb: fat bodies; In: intima; M: muscle; Mt: Malpighian tubule; N: nucleus; R: rupture; V: vacuole; Ta: taenidium; Tep: trachael epithelium; Tl: tracheal lumen. 
Morphologic abnormalities: Larvae, pupae, and emerging adult flies from larvae previously treated with the plant volatile oils and IMI exhibited a few similar morphologic abnormalities. As compared with normal larvae (Fig. 8a), larvae treated with the two volatile oils and IMI showed evidence of macerations. The treated larvae acquired dark color at the anterior end (Fig. 8b), in addition to severe shrinkage in larval skin (Fig. 8c). Unlike normal pupae (Fig. 8d), treatment of larvae with the tested compounds resulted in aberrant C-shaped or twisted pupae (Fig. 8e), inflated or balloon shaped pupae (Fig. 8f), and elongated or rod- shaped pupae (Fig. 9a); wrinkled puparium was observed (Fig. 9b). Most of the abnormal pupae obtained from treated larvae failed to reach adult stages (aborted puparia), while some emerged as adults with various degrees of morphological abnormalities. A dominance of incomplete adult egress was recorded varying from emergence of the head only (Fig. 9c), to the head and thorax (Fig. 9d, e). Some released adults were completely free but possessed abnormal appearance such as a strongly crumpled wing (Fig. 9f, g), and obvious severe deformation in the thorax and abdomen (Fig. 9h, i).
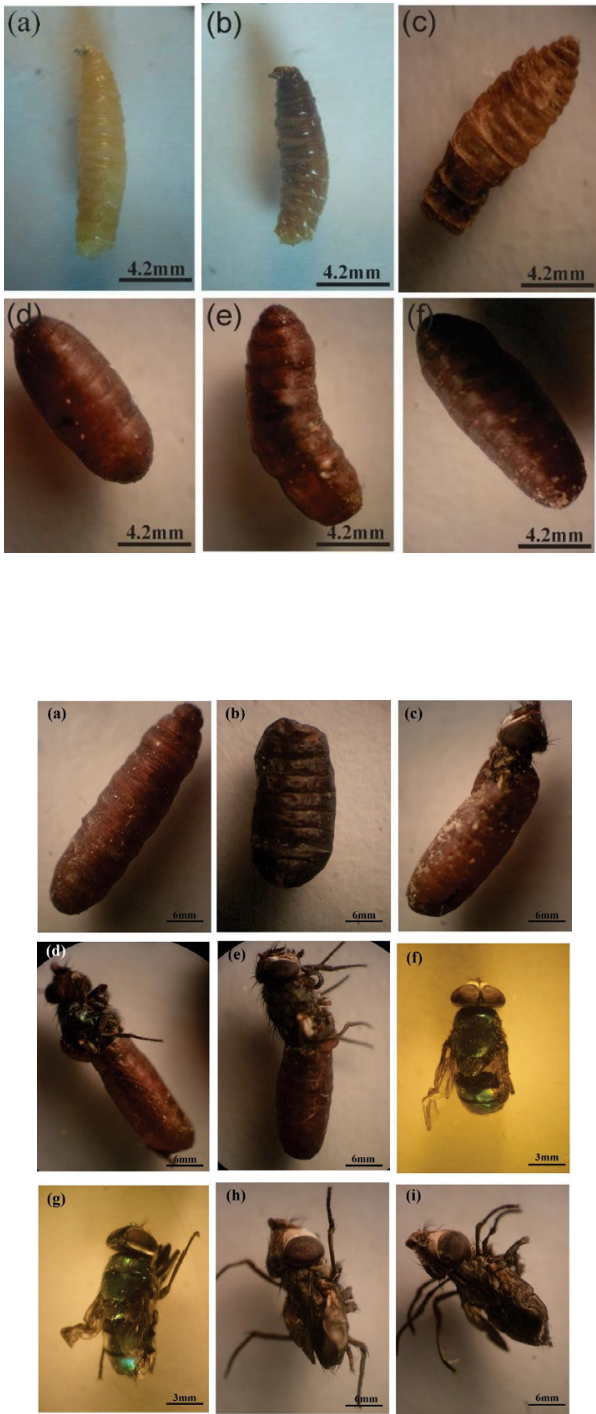

Fig. 8. Stereomicroscopic view of normal and deformed L. cuprina larva and pupa after treatment with $S$. aromaticum, M. longifolia volatile oils and IMI. a) Normal larva; b) Larva with dark pigmented cuticle; c) Larva with dried and shrunken cuticle; d) Normal pupa; e) Curved pupa; f) Balloon shaped pupa.
Fig. 9. Stereomicroscopic view of deformed L. cuprina pupa and adult after treatment with S. aromaticum, M. longifolia volatile oils and IMI: a) Elongated and rod-shaped pupa; b) Crumpled pupa; c-e) Incomplete adult emergence; c) Head only emerged from puparium; d, e) Head and part of thorax emerged from puparim, (legs and wing are glued with puparium); f-i) Adult deformations: $\mathbf{f}, \mathbf{g}$ ) Defective or crumpled wings; $\mathbf{h}$, i) Incomplete development of legs and deformed wings.

\section{DISCUSSION}

The target stage in the present study is the L3 instar as the principal agent in cutaneous and subcutaneous myiasis. The effect of compound application on this stage and the subsequent stages, pupae and adults emerged from treated larvae was observed. Pupae of treated larvae were deformed leading to emergence of deformed adults with crumpled wings, hence hampering their flight and spread of disease. Few studies were conducted on toxicological and histopathological effects of IMI on blow flies. The present study clearly demonstrates the strong impact of S. aromaticum and M. longifolia volatile oils as well as IMI on biology, histopathology, and AchE activity of the L3 of L. cuprina. A significant effect was induced on larval mortality after treatment with both volatile 
oils compared with IMI as the most effective larvicidal agent against L3 of L. cuprina. Previous studies on the toxicological effect of volatile oils against insects were recorded $^{[47,48]}$. Cymbopogon citrates oil and its active ingredient citral proved toxic against myiasis producing flies, Chrysomya megacephala, C. putoria and L. cuprina; and the highest mortality percent was recorded against $C$. megacephala ${ }^{[47]}$. Both Artemisia annua and A. dracunculus volatile oils displayed not only toxic effects but also repellent activities against Calliphora vomitoria ${ }^{[48]}$. The volatile oil of tea tree showed toxicological effect and inhibition of oviposition of L. cuprina ${ }^{[49]}$. Also, the volatile oil of Curcuma longa proved to be toxic against L3 of $L$. cuprina after filter paper impregnated treatment ${ }^{[50]}$. Volatile oils of Chrysopogon zizanioides, Cinnamomum zeylanicum, and Lavandula angustifolia showed insecticidal activities against L sericata $^{[51]}$. The essential oil of Ocimum sanctum Var. cubensis showed insecticidal activities against Chrysomya putoria ${ }^{[52]}$. Toxicity of volatile oils against insects is attributed to the presence of active oil ingredients ${ }^{[33-55]}$.

The mechanism of toxicity of volatile oils has not been fully identified. Several reports indicate that monoterpenoids of these oils may cause mortality in insects through inhibiting AchE activity ${ }^{[20,29,56]}$. The monoterpenes which are lipophylic, can penetrate cell membranes. This process can decline membrane transport, ion equilibrium and membrane potential and quickly intervene in the physiological functions of insects; moreover, mitochondrial dysfunction may lead to cell death. IMI is a neurotoxin that interferes with conduction of nerve impulses and blocks AchE receptors $^{[57]}$. It induces accumulation of acetylcholine and neuronal hyper-excitation, leading to convulsions and death within minutes ${ }^{[35]}$.

So far, this study is the first attempt to illustrate the histopathological effects of IMI on this myiasis producing fly. The three tested compounds showed the same histopathological effects with varying degrees of severity. Histological deteriorations in cuticle of larvae following treatments with $S$. aromaticum, M. longifolia and IMI can be summarized as complete disintegration in epicuticle in some regions and lack of differentiation between epicuticle, exocuticle and endocuticle. These results are in accordance with the findings of other authors on Chrysomyia albiceps using Cinnamomum zeylanicum volatile oil ${ }^{[58]}$. Detachment of cuticle from hypodermis, disintegration in the hypodermis and destruction of the basement membrane was recorded when Synthesomyia nudesita larvae were treated with Cupressus macrocarpa and Alpinia officinarum volatile oils ${ }^{[59]}$. Thinning of cuticle with separation of epidermal cell layer in some regions was detected after treatment of L. seicata larvae by dipping technique in camphor oil; and disruption of epidermal cells layer was observed after treatment of L3 with lavender oil ${ }^{[60]}$. Cuticle damage of L. cuprina larvae occurred due to exposure to volatile oil of Curcuma longa and its active ingredient, $\alpha$-phellanderene ${ }^{[61]}$. The histological changes in the present study showed a noticeable destruction and vacuolization of the fat body cells. Similar results were recorded in L. cuprina larvae after treatment with Tagetes minuta volatile oil ${ }^{[62]}$.

The currently recorded histopathological effect of $M$. longifolia, $S$. aromaticum and IMI on larval muscles ranged between slight degeneration in the form of fissures, to complete destruction. The gastric caecal epithelial cells showed different histological changes; some cells appeared degenerated, others appeared hypertrophied with enlarged lumen. In addition, the treatment induced severe effects on the midgut, where shrinkage in some epithelial cells and swelling of other cells were observed. The brush border of Malpighian tubules showed coagulation and detachment from epithelial cells. Furthermore, the trachea showed hypotrophy of tracheal epithelium, appearance of vacuoles in the taenidium and the tracheal lumen became collapsed leading to suffocation. Another report agrees with the results of the present investigation on $L$. cuprina using volatile oils and plant extract. The investigators applied methanol extract of Carum copticum against $C$. pipiens larvae and observed obliteration of microvilli, swallowing and vacuolization in the midgut cells ${ }^{[63]}$. The effect of ethanol extract of Melia azedarach on midgut and gastric caecae of larvae of C. quinquefasciatus, portrayed clear damage to the epithelial cells. The midgut columnar epithelial cells showed vacuolization and damaged microvilli ${ }^{[64]}$. Certain ingredients in essential oils have inhibiting effect against AchE activity ${ }^{[65]}$.

By searching in the literature there are a few studies concerned with the inhibitory effects of the volatile oils extracted from S. aromaticum, M. longifolia and IMI on AchE activity ${ }^{[32-34]}$. Recorded inhibitory effects on AchE activity was observed after treatment with the median lethal concentrations of compounds under investigation. The insignificant decrease in the enzyme activity after treatment by the IMI was consequently followed by that of $S$. aromaticum and $M$. longifolia volatile oils; indicating that AchE enzyme was more sensitive to IMI than to the two volatile oils. This result is in harmony with that recording the inhibitory effect on AchE enzyme activity in vitro by Salvia lavandulaefolia, Eucalyptus camaldulensis and Ocimum canum $^{[65]}$. The AchE inhibitory effect by Clinopodium nubigenum and Lavandula angustifolia volatile oils was reported against $L$. sericata ${ }^{[66]}$. Inhibition in the activity of insect AchE by several plant extracts and by some monoterpenes which are the most abundant constituents of volatile oils, was reported ${ }^{[67]}$. Monoterpenes are recognized as the most active component of essential oils that inhibit AchE activity, causing accumulation of acetylcholine which leads to continuous stimulation and finally paralysis and death ${ }^{[68]}$. The inhibition may be related 
to competition with the active site of the enzyme ${ }^{[69,70]}$. The essential oil of Artemisia dracunculus has 2-fold higher inhibitory effect on the AchE activity as compared to that of Artemisia annua essential oil ${ }^{[48]}$. The inhibitory effect on AchE of the moth Helicoverpa armigera (Hubner) was lower than those of the control after treatment with the volatile oil of Melaleuca alternifolia $^{[71,72]}$.

The botanical volatile oils and IMI exerted deformative effects on larvae, pupae and adult flies emerging from previously treated larvae; the three materials exhibited similar morphogenic abnormalities. The treated larvae failed to acquire pupal skin due to disturbance in melanization process and due to muscle paralysis. The morphological deformations especially of wings affect the ability of adult insects to fly and reproduce, so these materials may be considered an effective method for controlling this medicallyimportant fly. These results are in accordance with data reported on L3 of Chrysomyia albiceps treated with volatile oils of T. vulgaris, Z. officinale and C. Zeylanicum ${ }^{[58]}$. Larval deformations recorded in L3 of $L$. sericata after treatment by Trigonella foenum-graecum, Apium graveolens, Raphanus sativus, and Brassica compestris included shrinking, dark pigmentations and twisting (C-shaped) of larvae. The pupal abnormalities included cracked larval-pupal intermediate; adult deformity included defective wings and legs ${ }^{[73]}$. Lettuce volatile oil causes deformity of $L$. sericata larvae presenting as shrinking, black pigmentation, and C-shaped twisting of larvae. The observed adult deformations were described as diminuted size and crumpling of the wings and legs ${ }^{[74]}$. The essential oil of Cymbopogon citrates led to malformations of emerging adults including small-sized flies, deformed wings, and distorted abdomen in Chrysomya putoria ${ }^{[47]}$. Abnormalities in $L$. sericata larvae, pupae and adult insects were observed following treatment with Commiphora molmol and Balanites aegyptiaca ${ }^{[75]}$. Morphologic deformation in L3 of Cochliomyia macellaria such as darkening of cuticle, twisted larvae, and pupae was reported after treatment with Tagetes minuta volatile oil ${ }^{[76]}$. Treatment of Chrysomya putoria larvae with lower concentrations of Ocinum sanctum volatile oil caused morphological deformations in abdomen, legs, and wings of emerged adults $^{[52]}$. Incomplete hatching of adults with deformed legs and wings was observed after treatment of $L$. cuprina L3 with Piper gaudichaudianum essential oil ${ }^{[77]}$. Presence of morphological abnormalities of L. cuprina treated with volatile oil of Tagetes minuta was reported as deformations of pupae in the form of shrinking, twisting and larval-pupal intermediate and in the adult distortion of wings and legs, and incomplete adult hatching ${ }^{[78]}$. The deformities recorded herein after treatments by the two oils and IMI, showed that these compounds can inhibit metamorphosis, suggesting that this effect resembles that induced after treatment with insect's growth regulators ${ }^{[79]}$.
In conclusion, the inhibitory effects of the two volatile oils and IMI on the biology, histology and AchE activity suggested that they may be considered as control agents against this medically important insect. The inhibitory effect of the essential oils under investigation on the AchE enzyme activity suggested that the target of their toxicity on L. cuprina is neural. AchE enzyme was more sensitive to IMI than to the two volatile oils. The change in the AchE enzyme activity may be one of the main reasons of insect death.

Conflict of interest: There is no conflict of interest. Funding statement: No grant was received.

\section{REFERENCES}

1. Snoep JJ, Sol J, Sampimon OC, Roeters N, Elbers ARW, Scholten HW et al. Myiasis in sheep in the Netherlands. Vet Parasitol 2002; 106 (4): 357-363.

2. Prado e Castro C, Sousa JP, Arnaldos MI, Gaspar J, García MD. Blowflies (Diptera: Calliphoridae) activity in sun exposed and shaded carrion in Portugal. Ann Soc Entomol Fr 2011; 47(1-2): 128-139.

3. Kaufman GL, Gandevia BH, Bellas TE, Tovey ER, Baldo BA. Occupational allergy in an Entomological Research Centre. I. Clinical aspects of reactions to the sheep blowfly Lucilia cuprina. Br J Indian Med 1989; 46(7): 473-478.

4. Förster M, Sievert K, Messler S, Klimpel S, PfefferK. Comprehensive study on the occurrence and distribution of pathogenic microorganisms carried by synanthropic flies caught at different rural locations in Germany. J Med Entomol 2009; 46:1164-1166.

5. Greenberg B, Kowalski JA, Klowden MJ. Factors affecting the transmission of Salmonella by flies: natural resistance to colonization and bacterial interference. Infect Immun 1970; 2:800-809.

6. Mariluis JC, Lagar MC, Bellegarde EJ. Diseminación de enteroparásitos por Calliphoridae (Insecta, Diptera). Mem Inst Oswaldo Cruz 1989; 84:349-351.

7. Ghandour AM. Health hazards in humans and animals caused by imported livestock diseases in Saudi Arabia. In: Buttiker W, Krupp F (Eds.), Fauna of Saudi Arabia. NCWCD Riyadh and Pro Entomologia Basle Switzerland 1988; 9: 468-477.

8. David JAO, Rocha T, Caetano FH. Ultra-morphological characteristics of Chrysomya megacephala (Diptera, Calliphoridae) eggs and its eclosion. Micron 2008; 39(8): 1134-1137.

9. Heath AC, Bishop DM. Flystrike in New Zealand: An overview based on a 16-year study, following the introduction and dispersal of the Australian sheep blowfly, Lucilia cuprina Wiedemann (Dipteran: Calliphoridae). Vet Parasitol 2006; 137(3-4):333-344.

10. Plant JW. Sheep ectoparasite control and animal welfare. Small Rumin Res 2006; 62:109-112.

11. Bag D. Pesticides and health risks. Econ Polit Wkly 2000; 35:3381-3383. 
12. Levot GW. Cyromazine resistance detected in Australian sheep blowfly. Aust Vet J 2012; 90:433-437.

13. Sandeman RM, Levot GW, Heath AC, James PJ, Greeff JC, Scott MJ et al. Control of the sheep blowfly in Australia and New Zealand: Are we there yet? Int J Parasitol 2014; 44(12):879-891.

14. Regnault-Roger C, Vincent C, Arnason JT. Essential oils in insect control: low-risk products in a high-stakes world. Annu Rev Entomol 2012; 57:405-424.

15. Khani A, Asghari J. Insecticide activity of essential oils of Mentha longifolia, Pulicaria gnaphalodes and Achillea wilhelmsii against two stored product pests, the flour beetle, Tribolium castaneum, and the cowpea weevil, Callosobruchus maculatus. J Insect Sci 2012; 12(73):1-10.

16. Sahaf B, Moharramipour S, Meshkatalsadat M. Fumigant toxicity of essential oil from Vitez pseudonegundo against Tribolium castaneum (Herbst) and Sitophilus oryzae (L.). J Asia-Pacific Entomol 2008; 11(4):175-179.

17. Abdelgaleil A, Mohamed M, Badawy M, El-Aramis S. Fumigant and contact toxicities of monoterpenes to Sitophilus zeamais (L.) and Tribolium castaneum (Herbst) and their inhibitory effects on acetylcholinestrase activity. J Chem Ecol 2009; 35(5):518-525.

18. Arasu MV, Al-Dhabi NA, Saritha V, Duraipandiyan V, Muthukumar C, Kim SJ. Antifeedant, larvicidal and growth inhibitory bioactivities of novel polyketide metabolite isolated from Streptomyce ssp AP-123 against Helicoverpa armigera and Spodoptera litura. BMC Microbiol 2013; 13(1):105.

19. Huang Y, Tan J, Kini R, Ho S. Toxic and antifeedant action of nutmeg oil against Tribolium castaneum (Herbst) and Sitophilus zeamais (Motsch.). J Stored Prod Res 1997; 33(4):289-298.

20. Waliwitiya R, Kennedy C, Lowenberger C. Larvicidal and oviposition altering activity of monoterpenoids, trans- anethole and rosemary oil to the yellow fever mosquito Aedes aegypti (Diptera:Culicidae). Pest Manag Sci 2008; 65(3):241-248.

21. Tawatsin A, Asavadachanukorn $\mathrm{P}$, Thavarva $\mathrm{U}$ Wongsinkongman P, Bansidhi T, Chavalitumrong $\mathrm{P}$ et al. Repellency of essential oils extracted from plants of Thailand against four mosquito vectors (Diptera: Culicidae) and oviposition deterrent effects against Aedes aegypti (Diptera: Culicidae). Southeast Asian J Trop Med Public Health 2006; 37(5):915-931.

22. Pavela R, Benelli G. Essential oils as ecofriendly biopesticides? Challenges and constraints. Trends Plant Sci 2016; 21(12):1000-1007.

23. Stamenkovic V. Revised and Expanded. $2^{\text {nd }}$ ed. Leskovac: NIGP Trend; 2005. Our Non-Harming Medicinal Herbs.

24. Naghibi F, Mosaddegh M, Motamed SM, Ghorbani A. Labiatae family in folk medicine in Iran: from ethnobotany to pharmacology. Iran J Pharm Res 2005; 4: 63-79.

25. Pérez Raya MD, Utrilla MP, Navarro MC, Jiménez J. CNS activity of Mentha rotundifolia and Mentha longifolia essential oil in mice and rats. Phytother Res 2006; 4(6):232-234.

26. Pascual-Villalobos MJ, Robledo A. Screening for anti-insect activity in Mediterranean plants. Ind Crops Prod 1998; 8(3):183-194.

27. Atal CK, Kapur BM. Cultivation, and utilization of aromatic plants. CSIR, Jammu-Tawi India 1982; 136-741.

28. Lee KG, Shibamoto T. Antioxidant property of aroma extract isolated from clove buds [Syzygium aromaticum (L.) Merr. Et Perry]. Food Chem 2001; 74(4):443-448.

29. Huang Y, Ho SH, Lee HC, Yap YL. Insecticidal properties of eugenol, isoeugenol and methyleugenol and their effects on nutrition of Sitophilus zeamais Motsch. (Coleoptera: Curculionidae) and Tribolium castaneum (Herbst) (Coleoptera: Tenebrionidae). J Stored Prod Res 2002; 38(5):403-412.

30. Velluti A, Sanchis V, Ramos AJ, Marı'n S. Inhibitory effect of cinnamon, clove, lemon grass, oregano and palmarose essential oils on growth and fumonis in B1 production by Fusarium proliferatum in maize grain. Int J Food Microbiol 2003; 84(10):1141-1146.

31. Jeschke P, Nauen R, Schindler M, Elbert A. Overview of the status and global strategy for neonicotinoids. J Agric Food Chem 2011; 59(7):2897-2908.

32. Tomizawa M, Casida JE. Selective toxicity of neonicotinoids attributable to specificity of insect and mammalian nicotinic receptors. Ann Rev Entomol 2003; 48:339-364.

33. Tomizawa $M$, Casida JE. Neonicotinoid insect toxicology: mechanisms of selective action. Ann Rev Pharmacol Toxicol 2005; 45: 247-268.

34. Matsuda K, Buckingham SD, Kleier D, Rauh JJ, Grauso M, Sattelle, DB. Neonicotinoids: insecticides acting on insect nicotinic acetylcholine receptors. Trends Pharmacol Sci 2001; 22(11):573-580.

35. Matsuda K, Shimomura M, Ihara M, Akamatsu M, Sattelle DB. Neonicotinoids show selective and diverse actions on their nicotinic receptor targets: electrophysiology, molecular biology, and receptor modelling studies. Biosci Biotechnol Biochem 2005; 69(8):1442-1452.

36. Ensley SM. Neonicotinoids. Veterinary Toxicology ( $3^{\text {rd }}$ Edition) Basic and Clinical Principles. RC Gupta (ed.). Academic Press 2018; 521-524.

37. Marcus C, Lichtenstein P. Biologically active components of anise toxicity and interaction with insecticides in insects. J Agric Food Chem 1979; 27:1217-1223.

38. Weaver DK, Wells CD, Dunkel FV, Bertsch W, Sing SE, Sriharan, S. Insecticidal activity of floral, foliar and root extracts of Tagetes minuta (Asteraceae) against Mexican bean weevils (Coleoptera: Bruchidae). J Econ Entomol 1994; 87(6):1718-1725.

39. Williams KA, Villet MH. Morphological identification of Lucilia sericata, Lucilia cuprina and their hybrids (Diptera, Calliphoridae). Zookeys 2014; 420:69-85.

40. Khater KS. Ultrastructural effects of chlorpyrifos and phenthoate on the midgut of Chrysomya albiceps larvae (Diptera: Calliphoridae). Egypt Acad J Biol Sci 2018; 10(1):49- 61. 
41. Smith KE, Wall R, Howard JJ. In vitro insecticidal effect of fipronil and beta-cyfluthin on larvae of the blowfly, Lucilia sericata. Vet Parasitol 2000; 88(3-4):261-268.

42. World Health Organization (WHO). Guidelines for laboratory and field testing of mosquito larvicides. Document WHO/CDS/WHOPES/GCDPP/13. Geneva: World Health Organization; 2005.

43. Bancroft J D, Gamble M. Theory and practice of histological techniques, 2007, $6^{\text {th }}$ edition, Churchill Livingston, London, New York, 100-112.

44. Simpson DR, Bulland DL, Linquist DA. A semimicrotechnique for estimation of cholinesterase activity in boll weevils. Ann Ent Soc Amer 1964; 57:367-371.

45. Reddy PJ, Krishna D, Murthy US, Jamil K. A microcomputer FORTRAN program for rapid determination of lethal concentration of biocides in mosquito control. CABIOS 1992; 8:209-213.

46. Costat Statistical Software. Microcomputer program analysis. Cohort Software, Version 4.2, Berkeley, CA, 1990.

47. Pinto ZT, Fernández-Sánchez F, Santos AR, Amaral ACF, Ferreira J P, Escalona-Arranz JC, et al. Effect of Cymbopogon citrates (Poaceae) oil and citral on postembryonic time of blowflies. J Entomol Nematol 2015; $7(6): 54-64$.

48. Bedini S, Flamini G, Cosci F, Ascrizz R, Echeverria MC, Guidi L et al. Artemisia spp. essential oils against the disease-carrying blowfly Calliphora vomitoria. Parasit Vectors 2017; 10:80.

49. Callander JT, James PJ. Insecticidal and repellent effects of tea tree (Melaleuca alternifolia) oil against Lucilia cuprina. Vet Parasitol 2012; 184:271-278.

50. Chaaban A, Richardi VS, Carrer AR, Brum JS, Cipriano RR, Martins CNE et al. Insecticide activity of Curcuma longa (leaves) essential oil and its major compound $\alpha$-phellandrene against Lucilia cuprina larvae (Diptera: Calliphoridae): Histological and ultrastructural biomarker assessment. Pestic Biochem Physiol 2019; 153:17-27.

51. Khater HF, Ali A M, Abouelella G A, Marawan M A, Govindarajan M, Murugan $\mathrm{K}$ et al. Toxicity and growth inhibition potential of vetiver, cinnamon, and lavender essential oils and their blends against larvae of the sheep blowfly, Lucilia sericata. Int J Dermatol 2018; 57(4):449-457.

52. Chil-Nunez I, Mendoca PM, Escalona-Arrvanz J, Cortinhas LB, Dutok-Sanchez CM, Queiroz MMC. Insecticidal effects of Ocimum sanctum var. cubensis essential oil on the disease vector Chrysomya putoria, J Pharm Pharmacol Res 2018; 6(3):148-157.

53. Enan EE. Molecular response of Drosophila melanogaster tyramine receptor cascade to plant essential oils. Insect Biochem Mol Biol 2005 35(4):309-321.

54. Kilani S, Ledauphin J, Bouhlel I, Sghaier MB, Boubaker J, Skandrani I et al. Comparative study of Cyperus rotundus essential oil by a modifed GC/MS analysis method. Evaluation of its antioxidant, cytotoxic, and apoptotic effects. Chem. Biodivers 2008; 5(5):729742.

55. Mukandiwa L, Ahmed A, Eloff JN, Naidoo V. Isolation of seselin from Clausena anisata leaves and its effects on the growth and development of blowfly larvae. J Ethno Pharmacol 2013;150: 886-891.

56. Houghton PJ, Ren Y, Howes MJ. Acetylcholine esterase inhibitors from plants and fungi. Nat Prod Rep 2006; 23(2):181-199.

57. Bakkali F, Averbeck S, Averbeck D, Idaomar M. Biological effects of essential oils: A review. Food Chem Toxicol 2008; 46(2):446-475.

58. Sabry HM. The use of some biological control agents against a myiasis producing fly 2004; M.Sc. Thesis, Faculty of Sciences, Zagazig University, Egypt.

59. Khalaf AA, Hussein KT, Khater KS. Biocidal activity of two botanical volatile oils against the larvae of Synthesiomyia nudiseta (Wulp) (Diptera: Muscidae). Egypt Acad J Biol Sci 2009; 2(1):89-101.

60. Shalaby HA, El Khateeb RM, El Namaky AH, Ashry HM, Kandil OM, Abou El Dobal SKA. Larvicidal activity of camphor and lavender oils against sheep blowfly, Lucilia sericata (Diptera: Calliphoridae). J Parasit Dis 2015; 40(4): 1475-1482.

61. Chaaban A, Richardi VS, Carrer AR, Brumd, JS, Cipriano $\mathrm{RR}$, Martins CEN, et al. Cuticular damage of Lucilia cuprina larvae exposed to Curcuma longa leaves essential oil and its major compound $\alpha$-phellandrene. Data Brief 2018; 21:1776-1778.

62. Chaaban A, Santos VMC, Martins CEN, Brum JS, Bertoldi FC, Molento MB. Tissue damage and cytotoxic effects of Tagetes minuta essential oil against Lucilia cuprina. Exp Parasitol 2019; 198:46-52.

63. Al-Mekhlafi F. Larvicidal, ovicidal activities and histopathological alterations induced by Carum copticum (Apiaceae) extract against Culex pipiens (Diptera: Culicidae). Saud J Biol Sci 2017; 25:1.

64. Al-Mehmadi RM, Al-Khalaf AA. Larvicidal and histological effects of Melia azedarach extract on Culex quinquefasciatus Say larvae (Diptera: Culicidae). J King Saud Univ (Sciences). 2010; 22:77-85.

65. Savelev S., Okello E., Perry NSL, Wilkins RM, Perry EK. Synergistic and antagonistic interactions of anticholinesterase terpenoids in Salvia lavandulaefolia essential oil. Pharmacol Biochem Behav 2003; 75:661668.

66. Bedini S, Flamini G, Cosci F, Ascrizz R, Echeverria MC, Gomez EV et al. Toxicity and oviposition deterrence of essential oils of Clinopodium nubigenum and Lavandula angustifolia against the myiasis inducing blowfly Lucilia sericata. PLoS ONE 2019; 14(2): e0212576.

67. Ryan MF, Byrne O. Plant insect coevolution and inhibition of acetylcholine esterase. J Chem Ecol 1988; 14:1965-1975.

68. Corbett JR, Wright R, Baillie AC. The Biochemical Mode of Action of Pesticides, $2^{\text {nd }}$ ed. 1984; Academic Press, New York.

69. López MD, Pascual-Villalobos MJ. Mode of inhibition of acetylcholine esterase by monoterpenoids and 
implications for pest control. Ind Crop Prod 2010; 31: 284-288.

70. López MD, Pascual-Villalobos MJ. Are monoterpenoids and phenylpropanoids efficient inhibitors of acetylcholine esterase from stored product insect strains? Flavour Frag J 2015; 30:108-112.

71. Liao M, Xiao JJ, Zhou LJ, Yao X, Tang F, Hua RM, et al. Chemical composition, insecticidal and biochemical effects of Melaleuca alternifolia essential oil on the Helicoverpa armigera. J Appl Entomol 2017; 141:721728.

72. Burčul F, Blažević I, Radan M, Politeo O. Terpenes, phenylpropanoids, sulfur and other essential oil constituents as inhibitors of cholinesterases. Curr Med Chem 2020; 27(26): 4297-4343.

73. Khater HF, Khater DF. The insecticidal activity of four medicinal plants against the blowfly Lucilia sericata (Diptera: Calliphoridae). Int J Dermatol 2009; 48: 492497.

74. Khater HF, Hanafy A, Abdel-Mageed AD, Ramadan MY, El-Madawy RS. Control of the myiasis-producing fly, Lucilia sericata, with Egyptian essential oils. Int J Dermatol 2011; 50(2):187-194.

75. Mohamed HS, Fahmy MM, Attia MM, El Khateeb M, Shalaby HA, Massoud AM. The insecticidal activity of two medicinal plants (Commiphora molmol) and (Balanites aegyptiaca) against the blowfly Lucilia sericata (Diptera: Calliphoridae). Int J Adv Res Biol Sci 2016; 3(3):144-158.

76. Chaaban A, Fachini de Souza AL, Martins CEN, Bertoldi FC, Molento MB. Chemical composition of the essential oil of Tagetes minuta and its activity against Cochliomyia macellaria (Diptera: Calliphoridae). Eur J Med Plants 2017; 18(1):1-10.

77. Chaaban A, Santos VMC, Gomes E, Martins CEN, Amaral $\mathrm{W}$, Deschmaps C, et al. Chemical composition of Piper gaudichaudianum essential oil and its bioactivity against Lucilia cuprina (Diptera:Calliphoridae), J Essent Oil Res 2018; 30(3):159-166.

78. Chaaban A, Santos VMC, Martins CEN, Brum JS, Bertoldi FC, Molento MB. Effects of Tagetes minuta essential oil on Lucilia cuprina third instar larvae. Data Brief 2019; 25:104008.

79. Singh D, Siddiqui MS, Sharma S. Reproductive retardant and fumigant properties in essential oils against rice weevil (Coleoptera: Curculionidae) in stored wheat. J Econ Entomol 1989; 82:227-233. 